\title{
Integrated Weed Management in Soybean through Front Line Demonstration in Farmer's Field
}

\author{
R.K. Dwivedi ${ }^{1}$, N.K. Pandre ${ }^{2 *}$ and M.K. Ahirwar ${ }^{1}$ \\ ${ }^{1} J$. N. K. V. V. Krishi Vigyan Kendra Damoh (M.P.), India \\ ${ }^{2}$ J. N. K. V. V. Krishi Vigyan Kendra Sagar (M.P.), India \\ *Corresponding author
}

\section{A B S T R A C T}

\section{Keywords}

$\mathrm{B}: \mathrm{C}$ ratio, Front line demonstration Farmers practice, Recommended practice

\section{Article Info}

Accepted:

10 October 2019

Available Online:

10 November 2019
The front line demonstration on integrated weed management in soybean was conducted on farmers filed of Damoh district (MP) during kharif season of 2016-17 and 2017-18 at two different locations under rainfed conditions. Prevailing farmer practices were treated as control for comparison with recommended practice i.e. use of Integrated weed management practices such as preventive measure, cultural, mechanical and chemical methods i.e. application of Imazethapyr 35\%+Imazamox 35\% WG@70 g ai/ha at 15-20 days after sowing (DAS). The result of front line demonstration shows a greater impact on farming community due to significant increase in crop yield greater than farmers practice. The economics and benefit cost ratio of both farmers practice (FP) and recommended Practice (RP) were worked out. The weed intensity and weed biomass were found lower $\left(51.5 / \mathrm{M}^{2}\right.$ and $\left.45.7 \mathrm{~g} / \mathrm{m}^{2}\right)$ than FP $\left(275 / \mathrm{m}^{2}\right.$ and $\left.251 \mathrm{~g} / \mathrm{m}^{2}\right)$. An average of Rs. $26400 /$ ha was recorded net profit under RP, while it was Rs. 14300/ha under FP. Benefit cost Ratio was 2.49 under RP, while it was 1.73 under FP. By introducing the proven technology i.e. integrated weed management, yield potential and net income from soybean in rainfed conditions can be enhanced to a great extent with increase in the income level of the farming community of the District.

\section{Introduction}

Soyabean (Glycine max) belongs to family legumineaceae. It is mainly grown in Kharif season oilseed which is mostly grown under rainfed condition. The average productivity of soybean is $950 \mathrm{~kg} / \mathrm{ha}$ in Madhya Pradesh (2016-17) which is very low as compared to national productivity $(1450 \mathrm{~kg} / \mathrm{ha})$. The Main reasons for low productivity are due to abiotic and biotic factors. The biotic stresses are primarily unavoidable and are the most harmful in relation to growth and productivity of crops especially under rainfed areas.

Similarly, biotic stress are caused by living organism viz., weeds, insect, pests, disease, rodents etc 
Among biotic stresses weeds are major culprit which causes around 37\% yield reduction in soybean, hence weed management is an essential agronomic measure exploit the maximum yield potential of newly developed high yielding varieties (Choudhary et al., 2019; Indian farming 68(11)68-72). Therefore, use of weed management practices such as preventive measures, cultural, mechanical and chemical methods may be used in increase production of soybean.

Farmers utilized the resources mainly seeds. Fertilizers and insecticides on soybean but they ignore the integrated weed management practices. Hence an Effort was made by the KVK Scientist to demonstrate The integrated weed management practices i.e. preventive measures, stale seed bed, soil solarization, inter culture using harrow and finally use chemical weeding i.e. application of imazethapyr 35\%+Imazamax 35\%WG@70g ai/ha at 15-20 days after sowing on soybean during kharif season of 2016-17 and 2017-18.

\section{Materials and Methods}

The present study is a part of mandatory programme of Krishi Vigyan Kendra, Damoh (MP). Participatory Rural Appraisal (PRA), group discussion and transect walk were followed to explore the detail information of study area and between technology intervention, HRD component (Training/ kisan sangosthi /kisan mela/ field day etc) were also include to excel the farmers understanding and skill about the demonstrated technology on integrated weed management in soybean.

The front line demonstration conduct in twenty four farmers' field at Bamori and Jortala village on soybean JS 95-60 during kharif season of 2016-17 and 2017-18. Under RP plots use of integrated weed management practices such as preventive measure, cultural, mechanical and chemical methods i.e. application of Imazethapyr 35\%+Imazamax 35\%WG@70.9 g.i/ha at 15-20 DAS. While farmers practices (FP) plots as one hand weeding (uprooting) when weeds come to flowering stage. Data on weed intensity, weed biomass, No of pods/plant biological yield, harvest index (Table 1) and gross return (Rs/ha), B:C ratio were computed (Table 2). Finally the extension gap, technology gap and technology index (Table 3) were also calculated.

\section{Results and Discussion}

Frontline demonstration on integrated weed management in soybean was conducted by using most popular variety JS 95-60 in area 10ha at 24 farmers field in Jortala and Bamori village of Damoh District. Weed intensity and weed biomass were calculated at 30 DAS.

Under RP (recommended Practices) weed intensity and weed biomass were found lower $51.5 / \mathrm{m}^{2} \quad 45.7 \mathrm{~g} / \mathrm{m}^{2}$ (results concluded that average of two year) followed by $275 / \mathrm{m}^{2}$ and $251 \mathrm{~g} / \mathrm{m}^{2}$ in FP (farmers practice). The same trend found in case of net profit, an average of Rs. 40024/ha was recorded under RP, while it was Rs. 17217/ha under FP. Benefit cost Ratio was 2.49 under RP, while it was 1.76 under FP (Table 2).

In table 3 the extension gap i.e. 6.2q/ha during the period of study emphasized the need to educate the farmers through varies means for the adoption of improved technology. The trend of technology gap ranging between 5.6$6.3 \mathrm{q} / \mathrm{ha}$ reflected farmer's co-operation in carrying out such demonstration with encouraging results in both the years. The technology index showed the feasibility of the demonstrated technology at farmers field. The lower value of technology index, the more is the feasibility of the technology. 
Table.1 Performance of FLD as affected by recommended practices as well as farmers practices (Mean of two year 206-17, 2017-18)

\begin{tabular}{|c|l|c|c|}
\hline \multirow{2}{*}{ S.No. } & \multicolumn{1}{|c|}{ Parameters } & \multicolumn{2}{|c|}{ Treatment } \\
\cline { 3 - 4 } & & RP & FP \\
\hline 1. & Weed intensity $\left(\mathrm{No} / \mathrm{m}^{2}\right)$ & 51.5 & 275 \\
\hline 2. & Weed Biomass $(\mathrm{g} / \mathrm{m} 2)$ & 45.7 & 251 \\
\hline 3. & No of pod/plant $(\mathrm{No})$ & 65 & 40 \\
\hline 4. & Seed/pod (No) & 3 & 2 \\
\hline 5. & Grain yield (q/ha) & 19 & 12.8 \\
\hline 6. & Biological yield (q/ha) & 42.3 & 26.5 \\
\hline 7. & Harvest Index (\%) & 44.9 & 48.3 \\
\hline
\end{tabular}

Table.2 Economics of FLD as affected by RP as well as FP

\begin{tabular}{|c|c|c|c|c|c|c|c|c|c|c|c|}
\hline \multirow[t]{2}{*}{ Year } & \multicolumn{2}{|c|}{$\begin{array}{l}\text { Yield } \\
\text { q/ha }\end{array}$} & \multirow[t]{2}{*}{$\begin{array}{c}\text { \% increase } \\
\text { over FP }\end{array}$} & \multicolumn{2}{|c|}{$\begin{array}{c}\text { Gross Expenditure } \\
\text { Rs/ha }\end{array}$} & \multicolumn{2}{|c|}{$\begin{array}{l}\text { Grass income } \\
\text { Rs/ha }\end{array}$} & \multicolumn{2}{|c|}{ Net Profit } & \multicolumn{2}{|c|}{ B.C Ratio } \\
\hline & RP & FP & & RP & FP & RP & FP & RP & FP & RP & FP \\
\hline 2016-17 & 19.4 & 13.2 & 46.9 & 26410 & 23715 & 67176 & 40920 & 40766 & 17205 & 2.54 & 1.72 \\
\hline $2017-18$ & 18.7 & 12.5 & 46.6 & 27314 & 215 & 66596 & 38750 & 39282 & 17230 & 2.43 & 1.80 \\
\hline Mean & 19 & 12.8 & 48.2 & 26862 & 22618 & 66886 & 39835 & 40024 & 17217 & 2.49 & 1.76 \\
\hline
\end{tabular}

Table.3 Productivity, Technology gap, extension gap and Technology index of soybean as affected by RP as well as FP

\begin{tabular}{|c|c|c|c|c|c|c|c|c|c|}
\hline Year & $\begin{array}{c}\text { Area } \\
\text { (ha) }\end{array}$ & $\begin{array}{c}\text { No. of } \\
\text { farmer }\end{array}$ & \multicolumn{2}{|c|}{ Yield q/ha } & \multicolumn{2}{c|}{$\begin{array}{c}\text { \% increase } \\
\text { over FP }\end{array}$} & $\begin{array}{c}\text { Technology } \\
\text { Gap (q/ha) }\end{array}$ & $\begin{array}{c}\text { Extension } \\
\text { Gap (q/ha) }\end{array}$ & $\begin{array}{c}\text { Technology } \\
\text { Index }(\%)\end{array}$ \\
\hline & & & Potential & RP & FP & & & & \\
\hline $\mathbf{2 0 1 6 - 1 7}$ & 5 & 12 & 25 & 19.4 & 13.2 & 46.9 & 5.6 & 6.2 & 22.4 \\
\hline $\mathbf{2 0 1 7 - 1 8}$ & 5 & 12 & 25 & 18.7 & 12.5 & 49.6 & 6.2 & 6.2 & 25.2 \\
\hline Total/ Mean & 10 & 24 & 25 & 19 & 12.8 & 48.2 & 5.9 & 6.2 & 23.8 \\
\hline
\end{tabular}

As such, the reduction in technology index from $22.4 \%$ during 2016-17 to 25.2 during 2017-18 exhibited the feasibility of the demonstrated technology in this region.

Frontline demonstration on integrated weed management in soybean was conducted in two village of Damoh district and result concluded the average highest yield $19.4 \mathrm{q} / \mathrm{ha}$ in $\mathrm{RP}$ fallowed by $12.5 \mathrm{q} / \mathrm{ha}$ in $\mathrm{FP}$, means $55.2 \%$ gain.

It was observed that potential yield can be archived by imparting scientific knowledge to the farmers providing the quality need based input and proper application of integrated weed management. Horizontal spread of improved technology may be achieved by successful implementation of FLD and various extension activities in farmers' field.

\section{References}

Anonymous (2017) http;//economictimes. indiatimes.com/news may 9, 2016.

Choudhary, V.K., Kewat, M.L. and Singh, P.K. (2018). New approaches of weed management in soybean. Indian 
farming 68(11): 68-72.

Singh D, Patel AK, Bagel SK, Singh M.S., Singh A. and Singh AK (2014). Impact of front line demonstration on the yield and economics of chickpea in Sidhi district of MP. J. Agri. Research 1(1): $22-25$

\section{How to cite this article:}

Dwivedi, R.K., N.K. Pandre and Ahirwar, M.K. 2019. Integrated Weed Management in Soybean through Front Line Demonstration in Farmer's Field. Int.J.Curr.Microbiol.App.Sci. 8(11): 880-883. doi: https://doi.org/10.20546/ijcmas.2019.811.104 